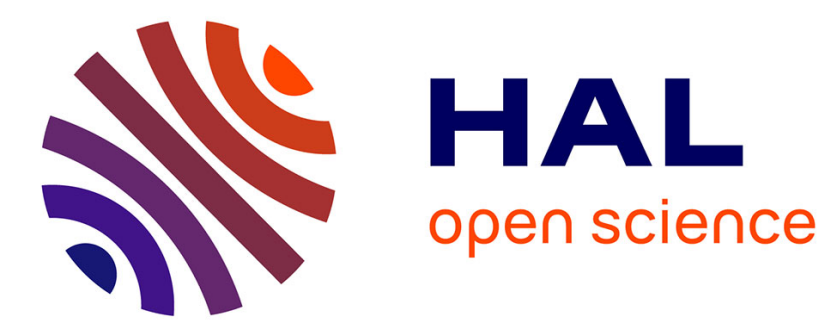

\title{
Hydrological Forecasting Practices in Brazil
}

F. Fan, R. Paiva, W. Collischonn, M.H. Ramos

\section{To cite this version:}

F. Fan, R. Paiva, W. Collischonn, M.H. Ramos. Hydrological Forecasting Practices in Brazil. EGU General Assembly 2016, Apr 2016, Vienna, Austria. Geophysical Research Abstracts, 18, pp.1, 2016. hal-02603532

\section{HAL Id: hal-02603532 \\ https://hal.inrae.fr/hal-02603532}

Submitted on 16 May 2020

HAL is a multi-disciplinary open access archive for the deposit and dissemination of scientific research documents, whether they are published or not. The documents may come from teaching and research institutions in France or abroad, or from public or private research centers.
L'archive ouverte pluridisciplinaire HAL, est destinée au dépôt et à la diffusion de documents scientifiques de niveau recherche, publiés ou non, émanant des établissements d'enseignement et de recherche français ou étrangers, des laboratoires publics ou privés. 
Geophysical Research Abstracts

Vol. 18, EGU2016-8608, 2016

EGU General Assembly 2016

(C) Author(s) 2016. CC Attribution 3.0 License.

\section{Hydrological Forecasting Practices in Brazil}

Fernando Fan (1), Rodrigo Paiva (1), Walter Collischonn (1), and Maria-Helena Ramos (2)

(1) Institute for Hydraulic Research, Federal University of Rio Grande do Sul, Porto Alegre, Brazil (rodrigo.paiva@ufrgs.br),

(2) Irstea, Hydrosystems and Bioprocesses Research Unit, 1, rue Pierre Gilles de Gennes, F- 92 761, Antony, France

This work brings a review on current hydrological and flood forecasting practices in Brazil, including the main forecasts applications, the different kinds of techniques that are currently being employed and the institutions involved on forecasts generation. A brief overview of Brazil is provided, including aspects related to its geography, climate, hydrology and flood hazards. A general discussion about the Brazilian practices on hydrological short and medium range forecasting is presented. Detailed examples of some hydrological forecasting systems that are operational or in a research/pre-operational phase using the large scale hydrological model MGB-IPH are also presented. Finally, some suggestions are given about how the forecasting practices in Brazil can be understood nowadays, and what are the perspectives for the future. 